\title{
Metabolit Sekunder dari Muntingia calabura dan Bioaktivitasnya
}

\author{
Devi Anggraini Putri dan Sri Fatmawati* \\ Laboratorium Kimia Bahan Alam dan Sintesis, Departemen Kimia, Institut Teknologi Sepuluh Nopember, \\ Kampus ITS Sukolilo, Surabaya, 61111 telp. (031) 5943353 \\ * Corresponding author \\ E-mail: fatma@chem.its.ac.id
}

DOI: 10.20961/alchemy.15.1.23362.57-78

Received 04 September 2018, Accepted 19 November 2018, Published 01 March 2019

\begin{abstract}
ABSTRAK
Muntingia calabura (Muntingiaceae) merupakan Jamaican cherry yang dikenal di Indonesia sebagai Kersen atau Talok. Metabolit sekunder sebagai konstituen kimia telah diisolasi dari daun, batang dan akar $M$. calabura. Flavonoid merupakan konstituen utama penyusun metabolit sekunder dari tanaman ini. Kelompok flavonoid telah dilaporkan memiliki efek farmakologi yang baik. Beberapa literatur melaporkan bioaktivitas M. calabura sebagai antioksidan, antidiabetes, antimikroba, antikanker, anti-inflamasi dan lain-lain. Review ini bertujuan memberikan fakta ilmiah terkait sinergitas metabolit sekunder dan bioaktivitas M. calabura yang diperlukan untuk penelitian kimia bahan alam lebih lanjut.
\end{abstract}

Kata kunci: bioaktivitas, flavonoid, metabolit sekunder, Muntingia calabura

\begin{abstract}
The secondary metabolites of Muntingia calabura and its bioactivity. Muntingia calabura (Mutingiaceae) was recognized as Jamaican cherry called as Kersen or Talok in Indonesia. The chemical constituents have been isolated from leave, stem and root of $M$. calabura. The main chemical constituent of the secondary metabolite is flavonoid. The flavonoid group has been reported as a good source in pharmacological aspect. Most of literatures reported that $M$. calabura has a good bioactivity as an antioxidant, antidiabetic, antimicrobial, anticancer, anti-inflammatory and others. This review aims to provide the scientific evidences related to the synergism of secondary metabolites and the bioactivities of $M$. calabura for further research on natural products.
\end{abstract}

Keywords: bioactivity, flavonoid, Muntingia calabura, secondary metabolite

\section{PENDAHULUAN}

Jamu atau obat tradisional telah dikonsumsi oleh sejumlah besar penduduk di dunia sebagai obat alternatif selama ratusan tahun. Selain itu, jamu juga digunakan sebagai suplemen kesehatan utama oleh sekitar $80 \%$ penduduk di negara berkembang di seluruh dunia. Sekitar $85 \%$ bahan dari obat tradisional melibatkan ekstrak tanaman. Bahkan, 
sejumlah obat-obatan modern atau sintetik dibuat dari hasil isolasi tanaman yang didasarkan pada obat-obat tradisional. Salah satu tanaman yang telah digunakan sebagai obat tradisional adalah Muntingia calabura. M. calabura dikenal di seluruh dunia sebagai Jamaican cherry dan di Indonesia, khususnya oleh penduduk Indonesia, M. calabura dikenal sebagai kersen atau talok (Mahmood et al., 2014). M. calabura berasal dari bagian selatan Mexico, daerah tropis selatan Amerika, Antilles, Trinidad dan St. Vincent. $M$. calabura secara luas dipelihara di daerah tropis seperti India dan Asia selatan yaitu Indonesia, Malaysia, Filipina dan Taiwan. Di Indonesia, M. calabura biasanya dikenal sebagai tanaman liar. Masyarakat di Indonesia biasanya mengkonsumsi buah M. calabura secara langsung karena rasanya yang manis, namun $M$. calabura belum dikenal secara luas sebagai obat tradisional. Sedangkan masyarakat Peru telah menggunakan bagian bunga dan batang dari $M$. calabura sebagai antiseptik dan mengurangi pembengkakan. Bagian daun yang telah direbus atau direndam dalam air, digunakan untuk mengurangi radang perut, pembengkakan pada kelenjar prostat, menurunkan sakit kepala dan demam. Selain itu, bagian batangnya juga dimanfaatkan untuk mengurangi pembengkakan pada luka. Di Colombia, infusi dari bunga digunakan sebagai obat penenang. Di Mexico, M. calabura digunakan sebagai pengobatan campak dan sakit perut. Di Filipina, bagian bunga digunakan sebagai obat sakit kepala atau demam, obat penenang, antispasmodik dan antidispeptik (Mahmood et al., 2014; Sufian et al., 2013)

Isolasi metabolit sekunder dari bagian akar (Kaneda et al., 1991), batang (Kuo et al., 2014; Chen et al., 2004) dan daun (Sufian et al., 2013; Yusof et al., 2013; Chen et al., 2007; Chen et al., 2005; Su et al., 2003) M. calabura telah dilaporkan. Sebagian besar metabolit sekunder yang dilaporkan merupakan golongan flavonoid seperti, calkon (Kuo et al., 2014; Sufian et al., 2013; Yusof et al., 2013; Chen et al., 2007; Chen et al., 2005; Su et al., 2003), flavanon (Kuo et al., 2014; Sufian et al., 2013; Yusof et al., 2013; Chen et al., 2007; Chen et al., 2005; Chen et al., 2004; Su et al., 2003), flavan (Kuo et al., 2014; Chen et al., 2007; Chen et al., 2004; Su et al., 2003; Kaneda et al., 1991) dan biflavan (Kaneda et al., 1991). Senyawa flavonoid telah diketahui memberikan efek farmakologi. Oleh karena itu, tanaman yang mengandung flavonoid banyak dimanfaatkan sebagai bahan obat herbal. Selain itu, beberapa penelitian telah melaporkan efek farmakologi dari M. calabura sebagai antioksidan (Buhian et al., 2017; Balan et al., 2015; Zakaria et al., 2014a; Sindhe et al., 2013; Gomathi et al., 2013; Preethi et al., 2012; Zakaria et al., 2011; Siddiqua et al., 2010; Preethi et al., 2010); anti-inflamasi (Balan et al., 2015; Zakaria et al., 2014a; 
Gomathi et al., 2013; Preethi et al., 2012; Zakaria et al., 2007a); antimikroba (Buhian et al., 2016; Rajesh et al., 2014; Sufian et al., 2013; Sibi et al., 2013; Sibi et al., 2012); antidiabetes (Khan et al., 2015; Sindhe et al., 2013; Sridhar et al., 2011); antikanker (Rofiee et al., 2015; Sufian et al., 2013; Chen et al., 2004; Chen et al., 2005; Kaneda et al., 1991); antinyeri (Zakaria et al., 2016; Zakaria et al., 2014b; Yusof et al., 2013; Sani et al., 2012; Zakaria et al., 2007b); antiulcer (Balan et al., 2015; Ibrahim et al., 2012) dan lainlain. Berdasarkan bioaktivitas M. calabura dari tinjauan tersebut, review ini bertujuan untuk memberikan fakta ilmiah terkait sinergitas senyawa metabolit sekunder dan aktivitas biologis dari $M$. calabura sebagai bahan acuan pada penelitian selanjutnya.

\section{Taksonomi dan Botani}

Berdasarkan studi literatur, M. calabura merupakan spesies tanaman yang termasuk ke dalam kingdom Plantae; orde Malvales; famili Muntingiaceace dan genus Muntingia L. Tanaman ini merupakan pohon hijau yang tingginya mencapai 3 - $12 \mathrm{~m}$. Tanaman ini terdiri atas bagian akar, batang, daun, bunga dan buah yang tumbuh di sepanjang tahun. Bagian daun berbentuk lonjong-bulat, menuju puncak semakin tajam, tepinya bergigi kecil dengan panjang $4-15 \mathrm{~cm}$ dan lebar $1-6 \mathrm{~cm}$. Bagian bunga berukuran kecil yaitu terdiri dari kelopak dengan diameter sekitar $1 \mathrm{~cm}$ dan jumlahnya sekitar 5 pasang. Bagian bunga terdiri dari banyak benang sari yang menyebar dan kepala sari yang berwarna kuning. Sedangkan bagian buah berbentuk bulat kecil dengan diameter sekitar 1,5 cm, berwarna hijau hingga merah pucat saat matang dan tersebar banyak pada pohon (Vijayanand and Thomas, 2016). Gambar 1 merupakan morfologi dari daun dan bunga M. calabura.

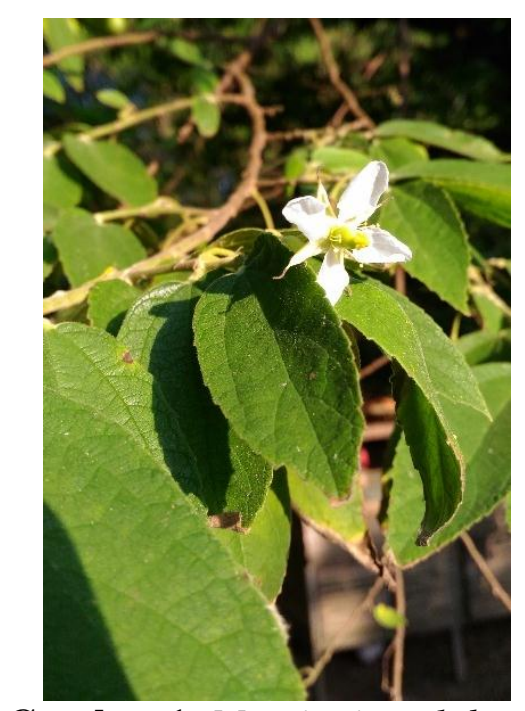

Gambar 1. Muntingia calabura 


\section{Isolasi Metabolit Sekunder}

Bagian dari tanaman $M$. calabura dari beberapa negara telah dilaporkan tentang isolasi metabolit sekunder dan efek farmakologinya. Isolasi metabolit sekunder dilakukan pada bagian daun, batang dan akar M. calabura dengan pelarut yang berbeda. Hasil isolasi sebagian besar menunjukkan flavonoid sebagai konstituen utama. Isolasi dari ekstrak metanol daun dari $M$. calabura yang dipartisi dengan etil asetat, petroleum eter, kloroform dan butanol dihasilkan sekitar 60 senyawa yang terdiri dari flavanon, calkon, flavon dan flavan. Isolasi dari ekstrak metanol batang dari $M$. calabura yang dipartisi dengan kloroform dan diklorometana dihasilkan sekitar 26 senyawa yang terdiri dari flavon, flavanon, flavan, biflavan dan calkon. Sedangkan isolasi dari ekstrak metanol akar $M$. calabura yang dipartisi dengan petroleum eter dihasilkan sekitar 11 senyawa diantaranya termasuk dalam kelompok flavon, flavan dan biflavan. Pada Tabel 1 dan Gambar 2 telah dilaporkan 99 metabolit sekunder yang diisolasi dari ekstrak daun, batang dan akar dari $M$. calabura yang tumbuh di berbagai belahan dunia.

\section{Isolasi Senyawa dari Daun}

Isolasi senyawa dari daun $M$. calabura yang berasal dari Peru dan Malaysia telah dilakukan dengan ekstraksi dan partisi yang sama. Hal ini ditunjukkan pada kesamaan pelarut yang digunakan saat proses ekstraksi maupun partisi. Metanol digunakan sebagai pelarut ekstraksi sedangkan petroleum eter, etil asetat dan aquades digunakan sebagai pelarut partisi (Sufian et al., 2013; Yusof et al., 2013; Su et al., 2003). Hasil dari proses partisi kemudian dilakukan fraksinasi lebih lanjut. Fraksinasi lebih lanjut yang dilakukan oleh Su et al. (2003) dan Sufian et al. (2013) diambil dari partisi etil asetat. Sedangkan fraksinasi lebih lanjut yang dilakukan oleh Izwan et al. (2013) diambil dari partisi petroleum eter. Meskipun bagian partisi yang diambil sama, namun teknik lebih lanjut dalam proses fraksinasinya berbeda. Su et al. (2003) melaporkan bahwa fraksinasi dari partisi etil asetat dilakukan dengan kromatografi kolom silika gel dengan gradien eluen kloroform:metanol (30:1 $\rightarrow$ 1:1) dihasilkan 12 fraksi. Fraksi ke-3 dan ke-4 kemudian dimurnikan lebih lanjut dengan kromatografi kolom silika gel dengan gradien eluen petroleum eter:aseton $(8: 1 \rightarrow 1: 1)$ sebagian besar dihasilkan senyawa flavonoid diantaranya 5 flavanon (1) (3) (5) (6) (12), 3 calkon (2) (4) (8), 7 flavon (7) (9) (13-17), 1 flavan (11) dan 1 asam fenolat (10) (Su et al., 2003). Fraksinasi lebih lanjut lainnya dari partisi etil asetat dilakukan dengan kromatografi kolom vakum dengan eluen $n$-heksana:etil asetat $(9: 1 \rightarrow 1: 9)$ dihasilkan 7 fraksi. Fraksi ke-5 kemudian dimurnikan lebih lanjut 
dengan kromatografi kolom silika gel dengan eluen $n$-heksana:etil asetat (9:1) dihasilkan 1 flavon (20) dan eluen $n$-heksana:kloroform:diklorometana (7:2:0,5) dihasilkan 2 flavon (18) (19) dan 1 calkon (4) (Sufian et al., 2013). Selanjutnya, Yusof et al. (2013) melaporkan fraksinasi dari partisi petroleum eter yang dilakukan dengan kromatografi kolom vakum dengan eluen $n$-heksana:etil asetat (9:1) dihasilkan 7 fraksi. Fraksi ke-4 kemudian dimurnikan lebih lanjut menghasilkan 2 flavon (21), (22), 1 calkon (23) dan 1 senyawa baru yang dinamakan calaburon (24) (Yusof et al., 2013).

Isolasi senyawa pada bagian daun $M$. calabura yang berasal dari Taiwan juga telah dilakukan dengan pelarut ekstraksi sama namun pelarut partisi dan fraksinasi lebih lanjut berbeda. Pada penelitian ini, metanol digunakan sebagai pelarut ekstraksi kemudian pelarut kloroform:aquades (1:1) dan $n$-butanol:aquades (1:1) digunakan sebagai pelarut partisi diperoleh masing-masing 15 fraksi yaitu 15 fraksi A (fraksi larut kloroform) dan 15 fraksi B (fraksi larut $n$-butanol). Selanjutnya, fraksinasi lebih lanjut dilakukan pada keduanya. Fraksi A dilakukan kromatografi kolom silika gel dengan beberapa gradien eluen yaitu $n$ heksana:etil asetat $(1: 0 \rightarrow 0: 9)$ dihasilkan 5 fraksi yang kemudian dilakukan kromatografi lapis tipis preparatif (KLTP) dihasilkan senyawa $\beta$-amirenon (41). Eluen diklorometana:metanol (20:1) dihasilkan 10 fraksi yang kemudian dilakukan KLTP dihasilkan 2 flavon (25) (42), 2 calkon (26) (48), 1 terpenoid (41), 2 tokospirol (44) (45), 1 quinon (46) dan asam isovanilat (47). Eluen $n$-heksana:etil asetat (7:1) dihasilkan 10 fraksi yang kemudian dilakukan KLTP dihasilkan 3 flavon (22) (27) (28), 1 calkon (29), 1 muntingon (30), 1 flavanon (31), 3 steroid (50) (51) (52). Untuk eluen $n$-heksana:etil asetat (4:1) dihasilkan 9 fraksi yang kemudian dilakukan KLTP dihasilkan 4 flavon (32) (33) (18) (14) dan 1 calkon (34). Selanjutnya untuk eluen diklorometana:metanol dihasilkan 15 fraksi yang dilakukan KLTP dihasilkan 3 flavanon (36) (37) (38), 3 calkon (35) (36) (53), 1 flavan (54), 1 fenolat (55), 2 flavon (56) (58), quinon (46) dan asam kumarat (57). Selain itu, fraksi B juga dilakukan kromatografi kolom silika gel dengan 2 jenis gradien eluen yaitu diklorometana:metanol (8:1) dihasilkan 7 fraksi yang kemudian dilakukan KLTP dihasilkan 2 senyawa galangin (39) (40) dan nitrofenol (59) dan eluen diklorometana:metanol (6:1) dihasilkan 10 fraksi yang dilakukan KLTP dihasilkan metil galat (60) (Chen et al., 2007; Chen et al., 2005).

\section{Isolasi Senyawa dari Batang}

Isolasi senyawa dari kulit batang $M$. calabura yang berasal dari Taiwan telah dilakukan dengan pelarut ekstraksi sama namun pelarut partisi dan fraksinasi lebih lanjut 
berbeda. Pada penelitian ini, metanol digunakan sebagai pelarut ekstraksi. Chen et al. (2004) melaporkan bahwa eluen aquades:kloroform (1:1) digunakan sebagai pelarut partisi yang kemudian dielusidasi lebih lanjut dengan eluen $n$-heksana:etil asetat (9:1) dihasilkan 13 fraksi. Fraksi ke-2 selanjutnya dilakukan kromatografi kolom dengan beberapa gradien eluen yaitu pertama eluen $n$-heksana:aseton (3:1) memperoleh 6 fraksi yang kemudian diperoleh 2 senyawa kosanol (61) dan (62) melalui KLTP. Selanjutnya, eluen $n$ heksana:etil asetat (8:1) memperoleh 10 fraksi yang kemudian melalui KLTP diperoleh senyawa sterol (63) dan (64). Terakhir, eluen kloroform:aseton (10:1) menghasilkan 5 flavon (65) (66) (69) (70) (71), 1 flavan (67), stigmaston (68), asam vanilat (72), propanon (73) dan asam syringat (74) (Chen et al., 2004). Kuo et al. (2014) juga telah melakukan isolasi senyawa pada batang $M$. calabura dengan pelarut ekstraksi yang sama yaitu metanol namun pelarut partisi dan fraksinasi berbeda dibandingkan oleh isolasi yang dilakukan Chen et al. (2004). Eluen diklorometana:aquades (1:1) digunakan sebagai pelarut partisi yang menghasilkan 3 fraksi (A-C). Pada penelitian ini, fraksinasi lebih lanjut difokuskan pada fraksi A. Fraksi A dilakukan kromatografi kolom silika gel dengan eluen diklorometana yang secara bertahap dinaikkan kepolarannya dengan metanol dihasilkan 11 fraksi. Fraksi ke-2 kemudian difraksinasi lebih lanjut menggunakan eluen $n$-heksana:etil asetat $(15: 1 \rightarrow 0: 1)$ untuk memperoleh 10 fraksi yang menghasikan senyawa sitosterol (63) melalui KLTP. Fraksi ke-3 difraksinasi dengan eluen diklorometana:metanol (15:1 $\rightarrow$ 0:1) untuk menghasilkan 9 fraksi yang memperoleh 1 senyawa flavon (76), 1 flavan (67) dan 1 flavanon (77). Selanjutnya, fraksi ke-4 difraksinasi dengan eluen kloroform:metanol (10:1 $\rightarrow$ 0:1) untuk memperoleh 12 fraksi yang menghasilkan 2 biflavan (78) (79), 2 flavon (80) (81) dan asam ferulat (82). Fraksi ke-5 difraksinasi dengan eluen kloroform:metanol (10:1 $\rightarrow$ 0:1) juga untuk memperoleh 10 fraksi lain yang menghasilkan 1 calkon (83), 1 flavanon (84) dan 1 flavan (85) melalui KLTP. Terakhir, fraksi ke-8 juga difraksinasi lebih lanjut dengan eluen diklorometana:metanol $(6: 1 \rightarrow 0: 1)$ untuk menghasilkan 8 fraksi yang menghasilkan senyawa asam galat (86) dan kuersetin (87) melalui KLTP (Kuo et al., 2014).

\section{Isolasi Senyawa dari Akar}

Isolasi senyawa pada bagian akar $M$. calabura belum banyak dilaporkan. Isolasi senyawa telah dilakukan pada bagian akar $M$. calabura yang berasal dari Filipina. Isolasi dilakukan dengan ekstraksi metanol yang kemudian dipartisi dengan petroleum eter. Hasil partisi dilakukan fraksinasi lebih lanjut dengan kromatografi kolom silika gel dengan 
kloroform (100\%) dan kloroform:metanol (9:1) dihasilkan 8 fraksi. Fraksi ke-5 kemudian dilakukan fraksinasi lebih lanjut dengan beberapa gradien eluen yaitu toluena:aseton (40:1 $\rightarrow$ 10:1) dihasilkan 7 flavan (88) (89) (90) (91) (92) (93) (94), untuk toluena:aseton (20:1 $\rightarrow$ 10:1) dihasilkan 2 flavon (95) (97) dan 2 biflavan (96) (98), terakhir dengan eluen toluena:aseton (7:1) dihasilkan 1 flavon (99) (Kaneda et al., 1991).

Tabel 1. Metabolit sekunder dari berbagai bagian M. calabura.

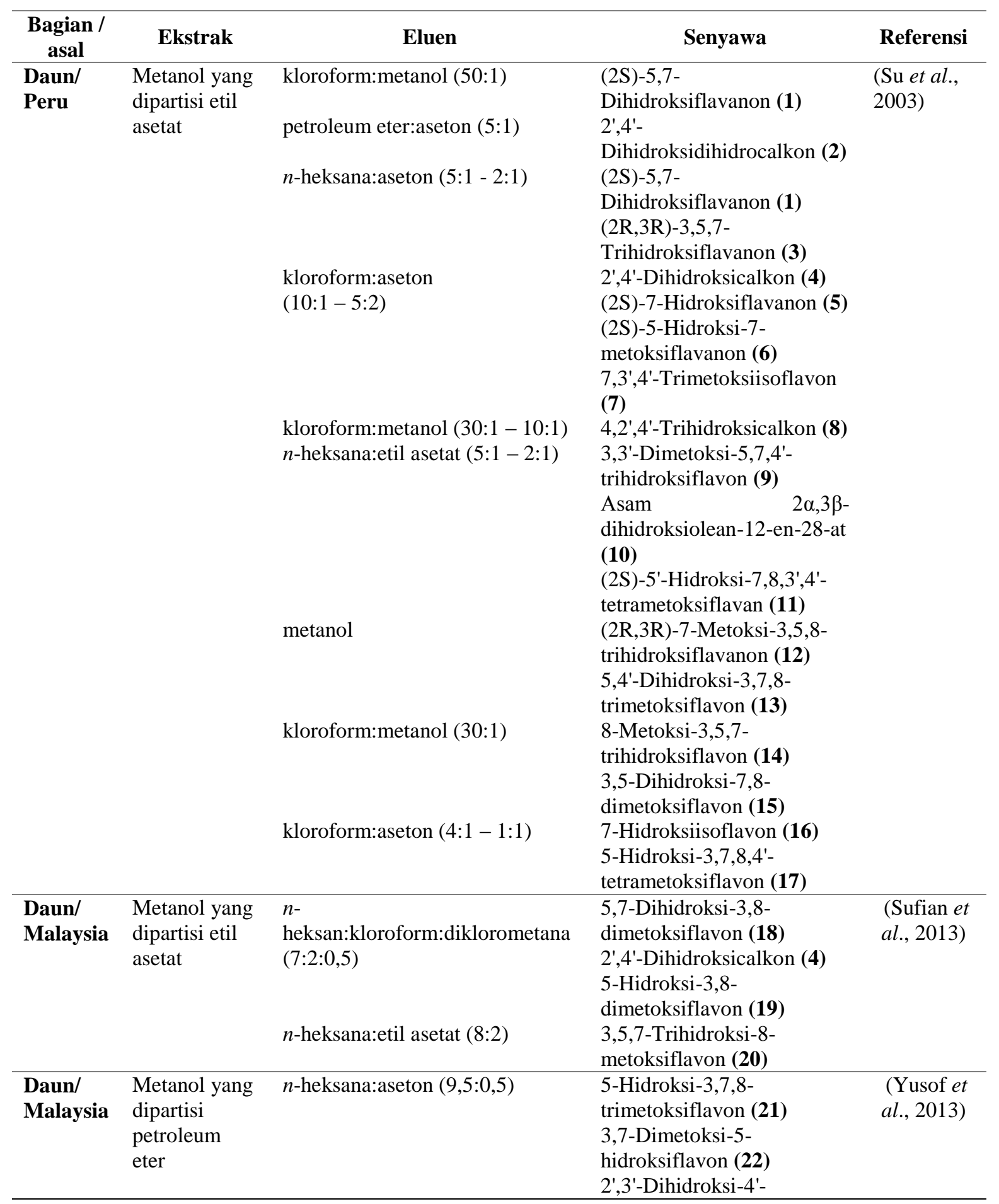


Tabel 1. Metabolit sekunder dari berbagai bagian M. calabura. (lanjutan)

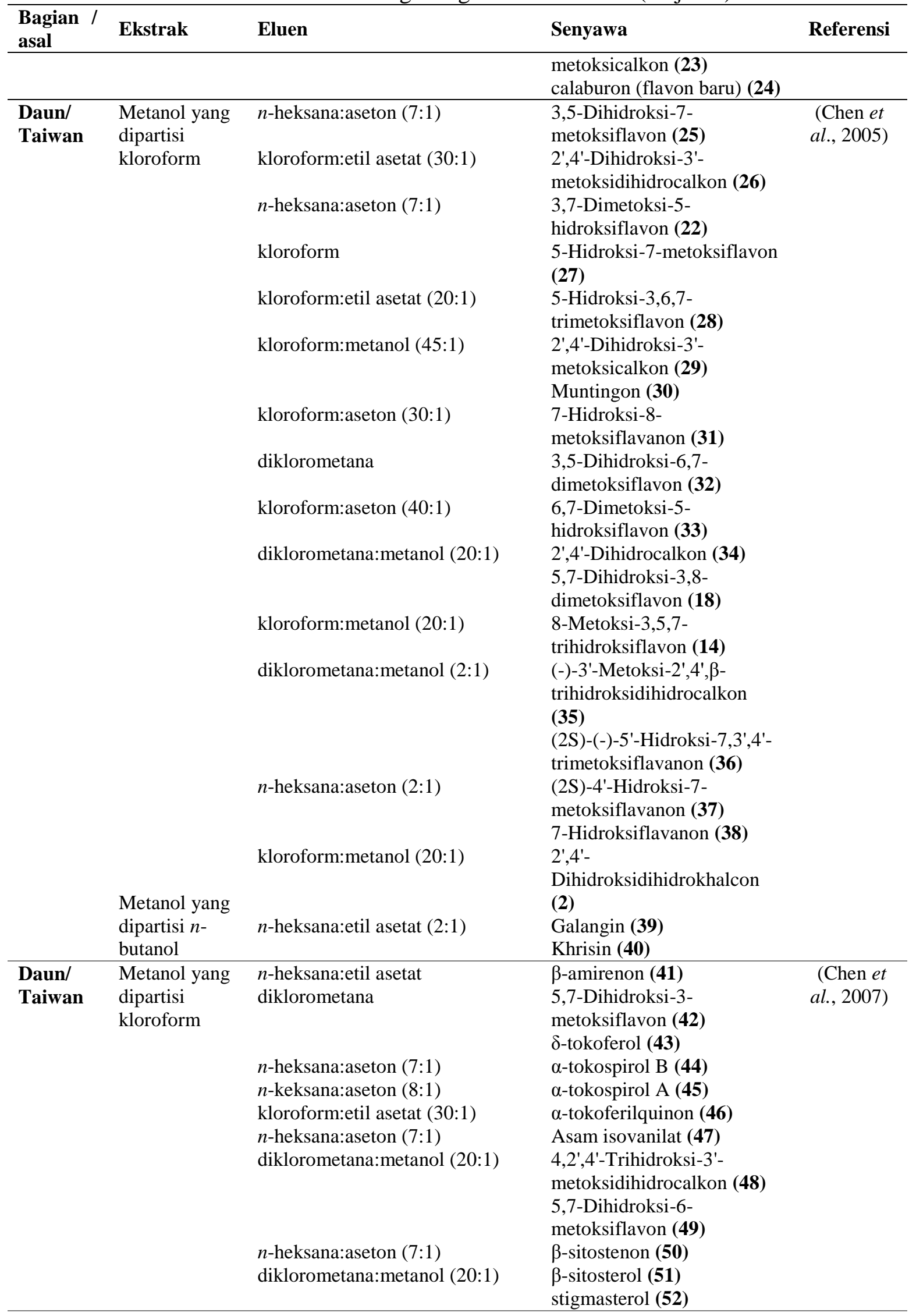


Tabel 1. Metabolit sekunder dari berbagai bagian M. calabura. (lanjutan)

\begin{tabular}{|c|c|c|c|c|}
\hline $\begin{array}{l}\text { Bagian / } \\
\text { asal }\end{array}$ & Ekstrak & Eluen & Senyawa & Referensi \\
\hline & $\begin{array}{l}\text { Metanol yang } \\
\text { dipartisi } n- \\
\text { butanol }\end{array}$ & $\begin{array}{l}\text { kloroform:aseton }(10: 1) \\
n \text {-heksana:aseton }(2: 1) \\
\text { kloroform:metanol }(2: 1) \\
\text { kloroform:metanol }(5: 1)\end{array}$ & $\begin{array}{l}\text { 2,3-Dihidroksi-4,3',4',5'- } \\
\text { tetrametoksidihidrocalkon } \\
\mathbf{( 5 3 )} \\
\text { 7,8,3',4',5'- } \\
\text { Pentametoksiflavan (54) } \\
\text { Metil-4-hidroksibenzoat } \\
\mathbf{( 5 5 )} \\
\text { 5,4'-Dihidroksi-3,7- } \\
\text { dimetoksiflavon (56) } \\
\alpha \text {-tokoferilquinon (46) } \\
\text { Trans-metil-p-koumarat } \\
\text { (57) } \\
\text { 7-Metoksiflavon (58) } \\
\text { p-nitrofenol (59) } \\
\text { Metil galat (60) }\end{array}$ & \\
\hline $\begin{array}{l}\text { Kulit } \\
\text { batang/ } \\
\text { Taiwan }\end{array}$ & $\begin{array}{l}\text { Metanol yang } \\
\text { dipartisi } \\
\text { kloroform }\end{array}$ & $\begin{array}{l}n \text {-heksana:etil asetat }(10: 1) \\
\text { kloroform:aseton }(20: 1) \\
n \text {-heksana:etil asetat }(1: 1) \\
\text { kloroform:aseton }(20: 1) \\
\text { diklorometana:metanol }(20: 1)\end{array}$ & $\begin{array}{l}\text { 1-Tetrakosanol (61) } \\
\text { 1-Heksakosanol (62) } \\
\beta \text {-sitosterol (63) } \\
\text { Tetrakosil ferulat (64) } \\
\text { 6,7-Dimetoksi- } \\
\text { hidroksiflavon (65) } \\
\text { 3,5-Dihidroksi-6,7- } \\
\text { dimetoksiflavon (66) } \\
\text { (2S)-5'-Hidroksi-7,8,3',4'- } \\
\text { tetrametoksiflavan (67) } \\
\text { 63-hidroksistigmast-4-en-3- } \\
\text { on (68) } \\
\text { 8-Hidroksi-7,3',4',5'- } \\
\text { tetrametoksiflavon (69) } \\
\text { 8,4'-Dihidroksi-7,3',5'- } \\
\text { trimetoksiflavon (70) } \\
\text { 5,7-Dimetoksiflavon (71) } \\
\text { Asam vanilat (72) } \\
\text { 3-Hidroksi-1-(3,5- } \\
\text { dimetoksi-4- } \\
\text { hidroksifenil)propan-1-on } \\
\text { (73) } \\
\text { Asam syringat (74) }\end{array}$ & $\begin{array}{r}\text { (Chen et } \\
\text { al., 2004) }\end{array}$ \\
\hline $\begin{array}{l}\text { Batang/ } \\
\text { Taiwan }\end{array}$ & $\begin{array}{l}\text { Metanol yang } \\
\text { dipartisi } \\
\text { diklorometana }\end{array}$ & $\begin{array}{l}\text { metanol } \\
n \text {-heksana:aseton }(10: 1) \\
\text { kloroform:aseton }(15: 1) \\
n \text {-heksana:aseton }(2: 1) \\
\text { n-heksana:aseton }(1: 1) \\
\text { n-heksana:aseton }(5: 1)\end{array}$ & 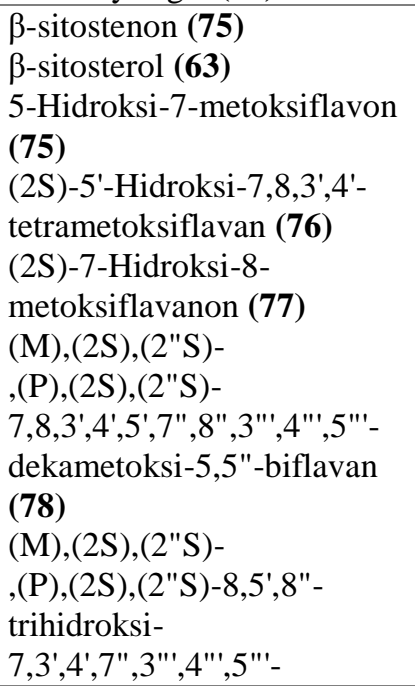 & $\begin{array}{c}\text { (Kuo et al., } \\
\text { 2014) }\end{array}$ \\
\hline
\end{tabular}


Tabel 1. Metabolit sekunder dari berbagai bagian M. calabura. (lanjutan)

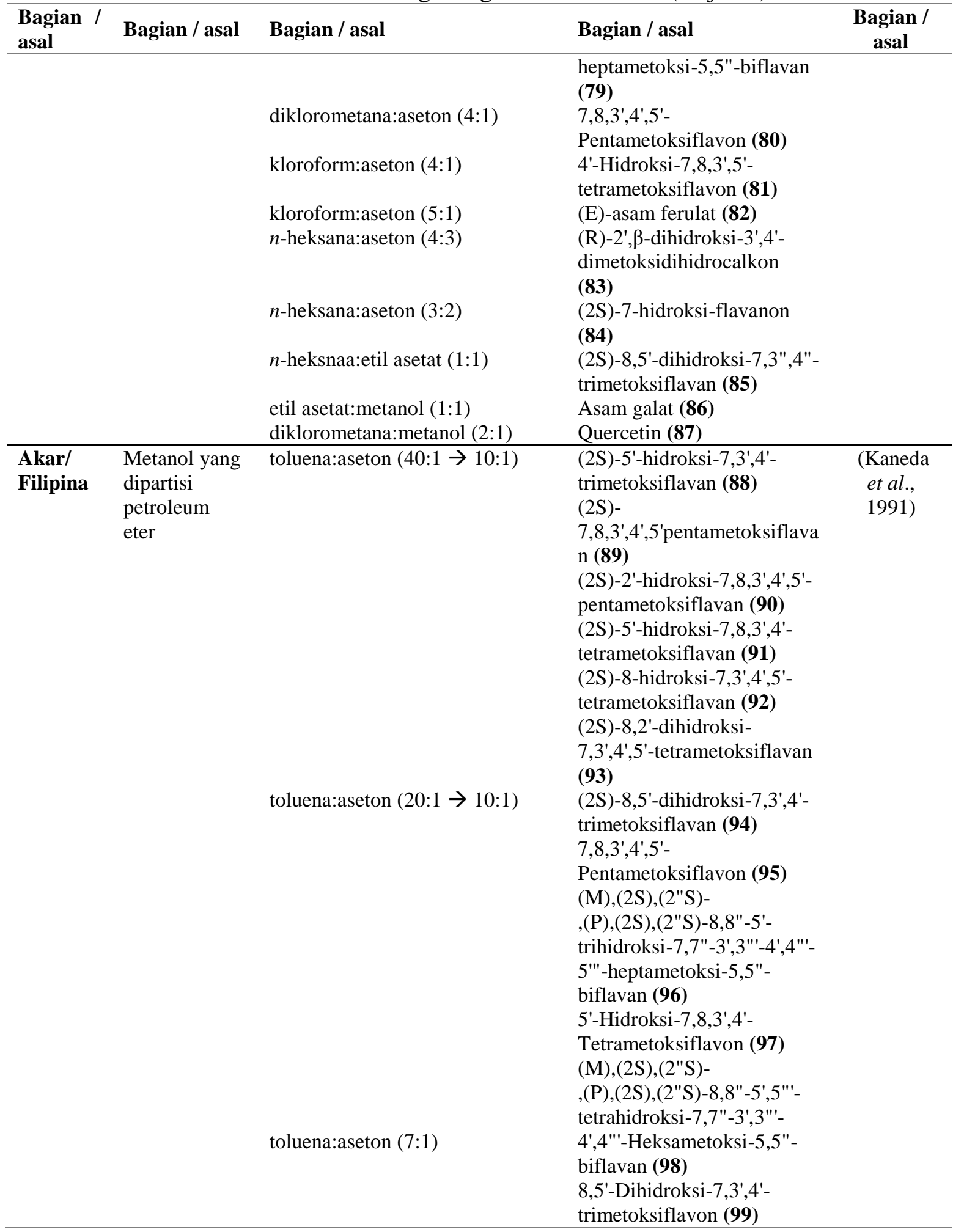


<smiles>[R9]c1cc(Br)c2c(c1Br)O[C@H](c1ccccc1)[C@H]([Y9])C2=O</smiles><smiles>[R]c1ccc(-c2oc3c([R9])c([R])cc([R])c3c(=O)c2[R])cc1[R]</smiles>

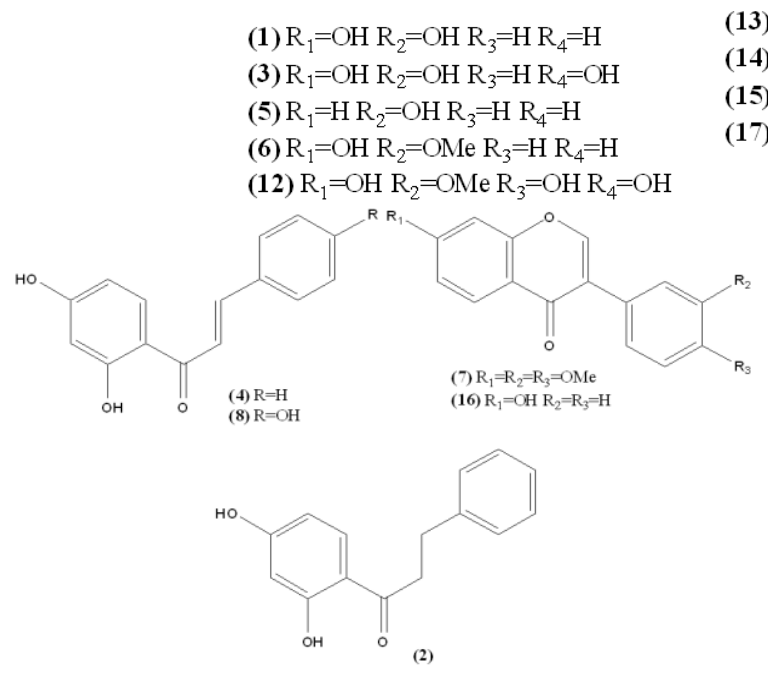

(13) $\mathrm{R}_{1}=\mathrm{OH} \mathrm{R} \mathrm{R}_{2}=\mathrm{OMe} \mathrm{R} \mathrm{R}_{3}=\mathrm{OMe} \mathrm{R} \mathrm{R}_{4}=\mathrm{H} \mathrm{R}_{5}=\mathrm{OH} \mathrm{R} \mathrm{R}_{6}=\mathrm{OMe}$

(14) $\mathrm{R}_{1}=\mathrm{OH} \mathrm{R} \mathrm{R}_{2}=\mathrm{OH} \mathrm{R} \mathrm{R}_{3}=\mathrm{OMe} \mathrm{R} \mathrm{R}_{4}=\mathrm{H} \mathrm{R}_{5}=\mathrm{H} \mathrm{R}_{6}=\mathrm{OH}$

(15) $\mathrm{R}_{1}=\mathrm{OH} \mathrm{R} \mathrm{R}_{2}=\mathrm{OMe} \mathrm{R} \mathrm{R}_{3}=\mathrm{OMe} \mathrm{R} \mathrm{R}_{4}=\mathrm{H} \mathrm{R}_{5}=\mathrm{H} \mathrm{R}_{6}=\mathrm{OH}$

(17) $\mathrm{R}_{1}=\mathrm{OH} \mathrm{R} \mathrm{R}_{2}=\mathrm{OMe} \mathrm{R} \mathrm{R}_{3}=\mathrm{OMe} \mathrm{R} \mathrm{R}_{4}=\mathrm{H} \mathrm{R}_{5}=\mathrm{OMe} \mathrm{\textrm {R } _ { 6 }}=\mathrm{OMe}$<smiles>COc1c(O)ccc(C(=O)/C=C/c2ccccc2)c1O</smiles>

(23)

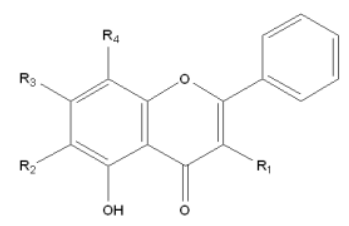

(25) $\mathrm{R}_{1}=\mathrm{OH} \mathrm{R} \mathrm{R}_{2}=\mathrm{R}_{4}=\mathrm{H} \mathrm{R}_{3}=\mathrm{OM}$ (27) $\mathrm{R}_{1}=\mathrm{R}_{2}=\mathrm{R}_{4}=\mathrm{H} \mathrm{R}_{3}=\mathrm{OMe}$ (28) $\mathrm{R}_{1}=\mathrm{R}_{2}=\mathrm{R}_{3}=\mathrm{OMe} \mathrm{R} \mathrm{R}_{4}=\mathrm{H}$ (32) $\mathrm{R}_{1}=\mathrm{OH} \mathrm{R} \mathrm{R}_{2}=\mathrm{R}_{3}=\mathrm{OMe} \mathrm{R} \mathrm{R}_{4}=\mathrm{H}$ (33) $\mathrm{R}_{1}=\mathrm{R}_{4}=\mathrm{H} \mathrm{R}_{2}=\mathrm{R}_{3}=\mathrm{OMe}$ (39) $\mathrm{R}_{1}=\mathrm{R}_{3}=\mathrm{OH} \mathrm{R}_{2}=\mathrm{R}_{4}=\mathrm{H}$ (40) $\mathrm{R}_{1}=\mathrm{R}_{2}=\mathrm{R}_{4}=\mathrm{H} \mathrm{R} \mathrm{R}_{3}=\mathrm{OH}$

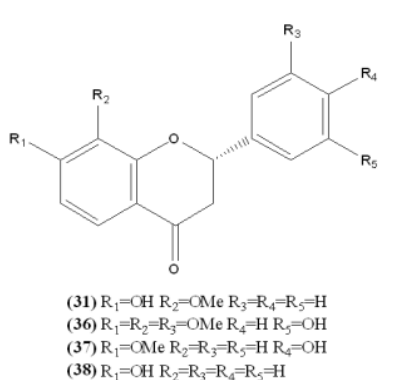

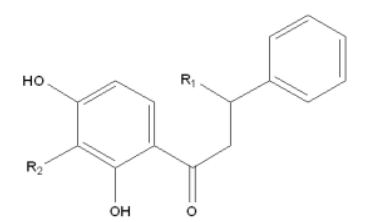

(26) $\mathrm{R}_{1}=\mathrm{HR}_{2}=\mathrm{OMe}$ (35) $\mathrm{R}_{1}=\mathrm{OH} \mathrm{R}_{2}=\mathrm{OM}$<smiles>O=c1c2c(oc3cc(O[Na])cc(O)c13)-c1ccccc1CO2</smiles>

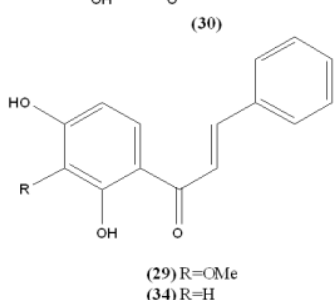

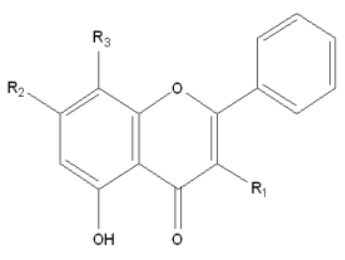

(18) $\mathrm{R}_{1}=\mathrm{R}_{3}=\mathrm{OMe} \mathrm{R}=\mathrm{OH}$ (19) $\mathrm{R}_{1}=\mathrm{R}_{2}=\mathrm{OH} \mathrm{R} \mathrm{R}_{3}=\mathrm{OMe}$ (20) $\mathrm{R}_{1}=\mathrm{R}_{2}=\mathrm{OMe} \mathrm{R}=\mathrm{H}$

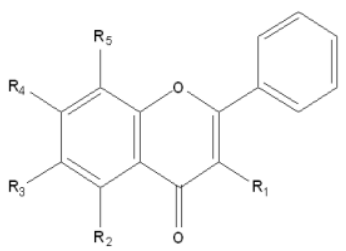

(21) $\mathrm{R}_{1}=\mathrm{R}_{4}=\mathrm{R}=\mathrm{OMe} \mathrm{R}=\mathrm{OH} \mathrm{R} \mathrm{R}_{3}=\mathrm{H}$ (22) $\mathrm{R}_{1}=\mathrm{R}_{4}=\mathrm{OMe} \mathrm{R} \mathrm{R}_{2}=\mathrm{OH} \mathrm{R} \mathrm{R}_{3}=\mathrm{R}_{5}=\mathrm{H}$ (24) $\mathrm{R}_{1}=\mathrm{R}_{2}=\mathrm{R}_{4}=\mathrm{H} \mathrm{R}_{3}=\mathrm{OMe} \mathrm{R}=\mathrm{OH}$

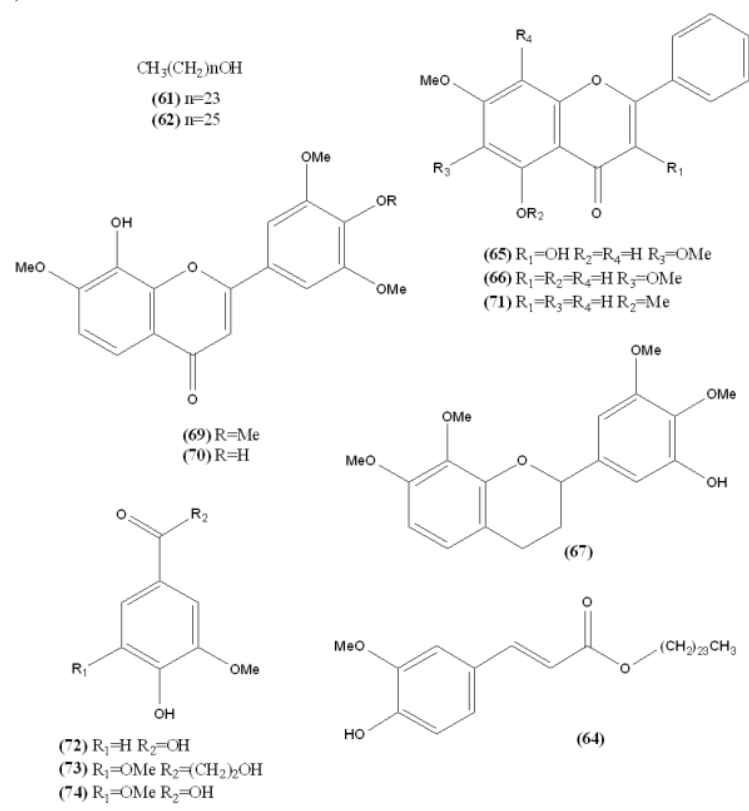

Gambar 2. Struktur 99 metabolit sekunder dari M. calabura. 

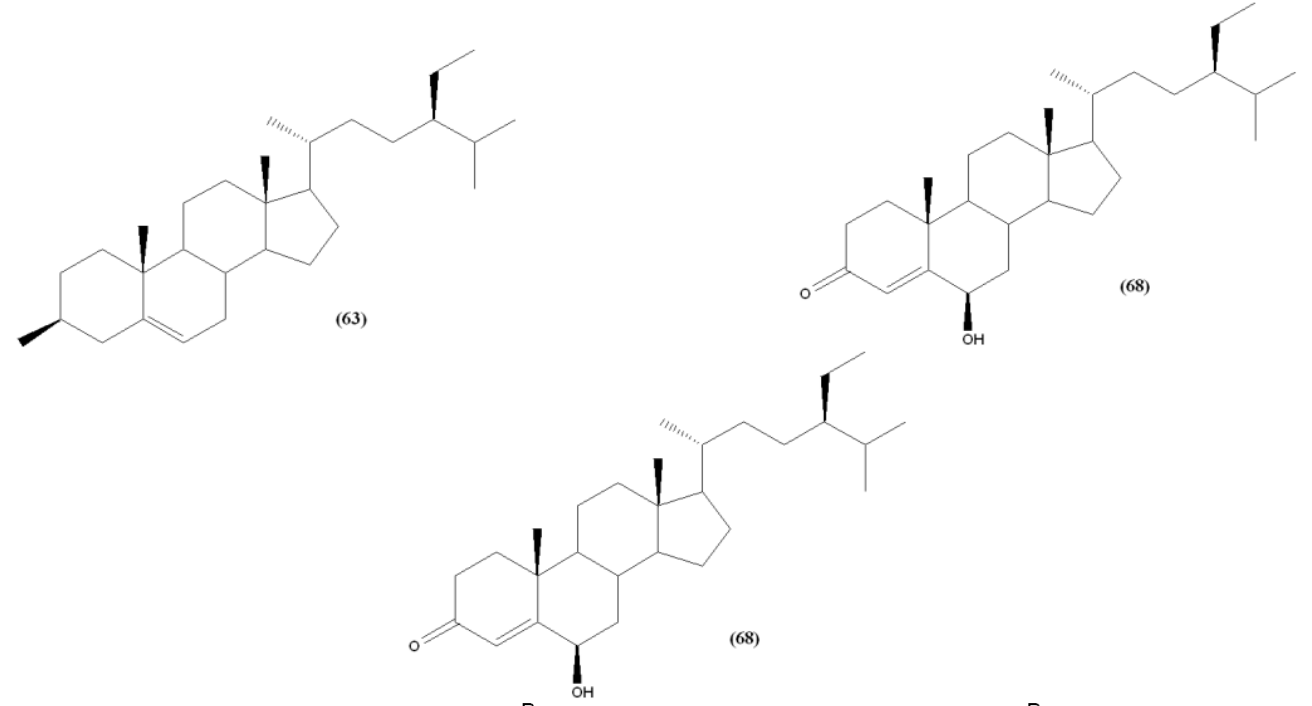<smiles>[R]c1ccc2c(=O)cc(-c3cc([R2])c([R5])c([R])c3)oc2c1</smiles>

(76) $\mathrm{R}_{1}=\mathrm{R}_{4}=\mathrm{R}_{5}=\mathrm{R}_{6}=\mathrm{R}_{7}=\mathrm{H} \mathrm{R}_{2}=\mathrm{OH} \mathrm{R} \mathrm{R}_{3}=\mathrm{OMe}$ (80) $\mathrm{R}_{1}=\mathrm{R}_{2}=\mathrm{H} \mathrm{R}_{3}=\mathrm{R}_{4}=\mathrm{R}_{5}=\mathrm{R}_{6}=\mathrm{R}_{7}=\mathrm{OMe}$ (87) $\mathrm{R}_{1}=\mathrm{R}_{2}=\mathrm{R}_{3}=\mathrm{R}_{5}=\mathrm{R}_{6}=\mathrm{OH} \mathrm{R} \mathrm{R}_{4}=\mathrm{R}_{7}=\mathrm{H}$

(77) $\mathrm{R}_{1}=\mathrm{R}_{2}=\mathrm{R}_{3}=\mathrm{OMe} \mathrm{R}=\mathrm{OH}$ (84) $\mathrm{R}_{1}=\mathrm{OH} \mathrm{R} \mathrm{R}_{2}=\mathrm{R}_{3}=\mathrm{R}_{4}=\mathrm{OMe}$<smiles>[R6]c1cc([C@H]2CCc3c(-c4cc(OC)c([R6])c5c4CC[C@@H](c4cc(OC)c(OC)c(OC)c4)O5)cc(OC)c([R8])c3O2)cc([18O])c1OC</smiles><smiles>COc1cc(-c2cc(=O)c3ccc(OC)c(OC)c3o2)cc(OC)c1O</smiles>

Gambar 2. Struktur 99 metabolit sekunder dari M. calabura. (lanjutan) 
<smiles>COc1cc([C@H]2CCc3ccc(O)c(O)c3O2)cc(O)c1O</smiles><smiles>[2H]c1cc([C@H]2CCc3ccc(O)c([2H])c3O2)c([2H])c([18OH])c1O</smiles>

(88) $\mathrm{R}_{1}=\mathrm{R}_{2}=\mathrm{H} \mathrm{R}=\mathrm{OH}$ (89) $\mathrm{R}_{1}=\mathrm{R}_{3}=\mathrm{OMe} \mathrm{R} \mathrm{R}_{2}=\mathrm{H}$ (90) $\mathrm{R}_{1}=\mathrm{R}_{3}=\mathrm{OMe} \mathrm{R} \mathrm{R}_{3}=\mathrm{OH}$ (91) $\mathrm{R}_{1}=\mathrm{OMe} \mathrm{R} \mathrm{R}_{2}=\mathrm{H} \mathrm{R}_{3}=\mathrm{OH}$ (92) $\mathrm{R}_{1}=\mathrm{OH} \mathrm{R} \mathrm{R}_{2}=\mathrm{H} \mathrm{R}_{3}=\mathrm{OMe}$ (93) $\mathrm{R}_{1}=\mathrm{R}_{2}=\mathrm{OH} \mathrm{R}=\mathrm{OMe}$ (94) $\mathrm{R}_{1}=\mathrm{R}_{3}=\mathrm{OH} \mathrm{R} \mathrm{R}_{2}=\mathrm{H}$<smiles>[R3]c1cc([C@H]2CC(=O)c3ccc(OC)c([R])c3O2)c([R2])c(OC)c1OC</smiles>

(95) $\mathrm{R}_{1}=\mathrm{R}_{3}=\mathrm{OMe} \mathrm{R}=\mathrm{H}$ (96) $\mathrm{R}_{1}=\mathrm{OMe} \mathrm{R} 2=\mathrm{H} \mathrm{R}_{3}=\mathrm{OH}$ (99) $\mathrm{R}_{1}=\mathrm{R}_{3}=\mathrm{OH} \mathrm{R} \mathrm{R}_{2}=\mathrm{H}$<smiles>O=C(O)c1cc(O)c(O)c(O)c1</smiles>

(86)<smiles>COc1cc(-c2cc(O)c(O)c3c2CC[C@@H](c2cc(O)c(O)c(OC)c2)O3)cc(O)c1O</smiles>

Gambar 2. Struktur 99 metabolit sekunder dari M. calabura. (lanjutan)

\section{BIOAKTIVITAS}

\section{Antioksidan}

Reactive Oxygen Species (ROS) merupakan radikal berbahaya terhadap tubuh manusia (Hidayati et al., 2017). Bahaya radikal bebas dalam jangka panjang dihubungkan dengan penyakit kronis seperti kanker, diabetes, penyakit neurodegenerative dan kardiovaskuler (Putri et al., 2018). Sehingga, antioksidan diperlukan sebagai penangkal radikal bebas. Antioksidan merupakan konstituen kimia yang mampu menangkal radikal bebas dengan mendonorkan protonnya (Fitriana et al., 2016). Bagian dari ekstrak daun $M$. calabura yang berasal dari India, Malaysia dan Filipina telah diuji aktivitas antioksidannya. Uji aktivitas antioksidan telah dilakukan pada beberapa ekstrak daun $M$. 
calabura (EDMC) yaitu ekstrak metanol (EMDMC) (Balan et al., 2015; Zakaria et al., 2014a; Zakaria et al., 2011; Siddiqua et al., 2010), ekstrak etanol (EEDMC) (Buhian et al., 2017), ekstrak petroleum eter (EPEDMC) (Sindhe et al., 2013), ekstrak kloroform (EKDMC) (Sindhe et al., 2013; Zakaria et al., 2011), ekstrak etil asetat (EEADMC) (Sindhe et al., 2013) dan ekstrak aquades (EAQDMC) (Sindhe et al., 2013; Zakaria et al., 2011). Dari beberapa EDMC, EMDMC adalah ekstrak yang sering digunakan pada uji aktivitas antioksidan. Berdasarkan literatur, uji aktivitas antioksidan pada EDMC telah dilakukan dengan beberapa metode. Metode-metode tersebut antara lain penentuan penghambatan DPPH, superoksida, ORAC, total fenolat, total flavonoid dan logam kelat. Metode penentuan penghambatan pada DPPH dan total fenolat merupakan dua metode yang sering digunakan dalam penentuan aktivitas antioksidan EDMC dan diperoleh nilai antioksidannya sebesar 99,2 $\pm 0,0 \%$. Hasil uji menunjukkan bahwa EMDMC memberikan hasil penghambatan DPPH dan superoksida dalam konsentrasi $100 \mu \mathrm{g} / \mathrm{mL}$ serta total fenolat dalam konsentrasi $6,25 \mathrm{mg} / \mathrm{mL}$ paling tinggi dari pada EAQDMC dan EKDMC dengan nilai masing-masing 99,2 \pm 0,0\%; 95,5 $\pm 0,6 \%$ dan 2978,1 $\pm 4,34 \mathrm{mg} / 100 \mathrm{~g}$ asam galat (Zakaria et al., 2011). Sedangkan hasil uji terbaik dari penentuan total flavonoid dan logam kelat ditunjukkan oleh EPEDMC dan EEADMC masing masing 247,92 \pm 1,56 dan $123,316 \pm 0,54 \mu \mathrm{g} / \mathrm{mg}$ (Sindhe et al., 2013).

Bagian dari buah M. calabura yang berasal dari India juga telah dilaporkan sebagai antioksidan. Beberapa literatur melaporkan bahwa telah dilakukan uji aktivitas antioksidan pada beberapa ekstrak buah M. calabura (EBMC) yaitu ekstrak petroleum eter (EPEBMC) (Preethi et al., 2010), ekstrak kloroform (Vijayanand and Thomas, 2016; Preethi et al., 2010), ekstrak etil asetat (EEABMC), ekstrak butanol (EBBMC) (Preethi et al., 2010), ekstrak etanol (EEBMC) (Vijayanand and Thomas, 2016), ekstrak metanol (EMBMC) (Vijayanand and Thomas, 2016; Preethi et al., 2012; Preethi et al., 2010), ekstrak aquades (EAQBMC) (Vijayanand and Thomas, 2016) dan ekstrak campuran metanol:aseton:air (3:5:3) (Gomathi et al., 2013). Hasil uji menunjukkan bahwa EMBMC memberikan hasil penghambatan DPPH (94\% pada konsentrasi $500 \mu \mathrm{g} / \mathrm{mL}$ ) (Preethi et al., 2012) dan total fenolat sejumlah $1486 \mathrm{mg} / 100 \mathrm{~g}$ (Preethi et al., 2010). Hasil tersebut menunjukkan bahwa aktivitas penghambatan DPPH dan total fenolat dari EMBMC adalah paling baik diantara EBMC yang lain. Sedangkan hasil uji terbaik dari aktivitas radikal hidroksil yaitu 280,4 \pm 0,8 g/mL dan uji FRAP 70,00 \pm 0,00\% ditunjukkan oleh EKBMC. Selain itu, pada EPEBMC dilakukan uji aktivitas logam kelat yang menunjukkan hasil yang baik yaitu 
480,6 \pm 0,02 g/mL, pada EEABMC juga menunjukkan aktivitas penghambatan radikal nitrit oksida yang baik sebesar 497,2 $\pm 0,08 \mathrm{~g} / \mathrm{mL}$ (Preethi et al., 2010) dan pada EEBMC dilakukan uji penghambatan CUPRAC dengan nilai penghambatan moderat sebesar 55,6 \pm 0,00\% (Vijayanand and Thomas, 2016).

Bagian dari batang dan akar $M$. calabura belum banyak dikaji aktivitas antioksidannya. Beberapa literatur melaporkan bahwa bagian batang M. calabura yang berasal dari Filipina dan bagian akar M. calabura yang berasal dari India telah diuji aktivitas antioksidannya. Uji aktivitas antioksidan dilakukan pada ekstrak etanol batang $M$. calabura (EEBTMC) dan ekstrak aquades akar M. calabura (EAQAMC). Hasil uji menunjukkan aktivitas antioksidan yang baik. Hal ini dapat dilihat pada hasil uji penghambatan DPPH memberikan prosentase penghambatan yang baik pada EEBTMC $(93,9 \pm 2,2 \%)$ pada konsentrasi $4 \mathrm{mg} / \mathrm{mL}$ (Buhian et al., 2017) dan EAQAMC dengan nilai penghambatan $61 \%$ dibandingkan dengan kontrol positif asam askorbat (58\%) dalam konsentrasi masing-masing $400 \mu \mathrm{M}$ (Khan et al., 2015).

\section{Antidiabetes}

Diabetes mellitus merupakan gangguan metabolisme makhluk hidup yang disebabkan oleh kekurangan insulin atau ketidakfungsian insulin yang ditandai dengan meningkatnya kadar gula dalam darah atau disebut sebagai hiperglikemia (Fatmawati et al., 2011a; 2011b). Peran antidiabetes adalah sebagai inhibitor pemecahan karbohidrat menjadi glukosa untuk menormalkan kadar gula dalam darah. Aktivitas antidiabetes pada bagian daun dari $M$. calabura yang berasal dari India telah dilaporkan oleh Sridhar et al. (2011) dan Sindhe et al. (2013). Sridhar et al. (2011) melaporkan bahwa uji antidiabetes dilakukan pada ekstrak metanol daun $M$. calabura (EMDMC) secara in vivo menggunakan tikus jantan jenis wistar yang dibuat diabetes. Hasil uji menunjukkan bahwa ketiga kelompok tikus uji mampu menurunkan kadar glukosa dengan nilai masing-masing 23,92 $\pm 1,81 ; 93,71 \pm 0,81$; dan 43,76 $\pm 4,75 \mathrm{mg} / \mathrm{dl}$ selama 8 hari (Sridhar et al., 2011).

Penelitian selanjutnya dilakukan oleh Sindhe et al. (2013) yaitu uji antidiabetes dilakukan secara in vivo dengan tikus jantan dewasa jenis wistar strain albino yang kemudian ditambahakan ekstrak kloroform daun M. calabura (EKDMC), ekstrak etanol (EEDMC) dan ekstrak aquades (EAQDMC) ke dalam tubuh tikus yang dibuat diabetes selama 14 hari. Hasil uji menunjukkan bahwa tikus diabetes yang diberi $1000 \mathrm{mg} / \mathrm{Kg}$ EEDMC mampu menurunkan kadar glukosa plasma lebih baik dari pada tikus diabetes yang diberi ekstrak lain sebesar $120 \pm$ 
$0,17 \mathrm{mg} / \mathrm{dl}$ selama 14 hari dibandingkan dengan tikus diabetes yang diberi glibenklamida $148,85 \pm 1,87 \mathrm{mg} / \mathrm{dl}$ (Sindhe et al., 2013).

Khan et al. (2015) melaporkan bahwa uji antidiabetes dilakukan pada ekstrak aquades akar M. calabura (EAQAMC) yang berasal dari India dengan uji aktivitas penghambatan pada enzim $\alpha$-amilase dan $\alpha$-glukosidase secara in vitro. Hasil uji menunjukkan bahwa aktivitas penghambatan pada $1000 \mu \mathrm{g} / \mathrm{mL}$ EAQAMC mencapai 67,23 $\pm 0,23 \%$, lebih tinggi dari pada $1000 \mu \mathrm{g} / \mathrm{mL}$ standar akarbosa $(65,24 \pm 0,00 \%)$. Sedangkan uji penghambatan pada enzim $\alpha-$ glukosidase terhadap EAQAMC diukur dengan metode oksidasi peroksidase glukosidase. Hasil uji menunjukkan bahwa aktivitas penghambatan pada $1000 \mu \mathrm{g} / \mathrm{mL}$ EAQAMC mencapai $78,33 \pm 0,31 \%$, lebih rendah dibandingkan dengan $1000 \mu \mathrm{g} / \mathrm{mL}$ standar akarbosa $(84,21 \pm$ 0,00\%) (Khan et al., 2015).

\section{Antimikroba}

Aktivitas antimikroba yang meliputi antibakteri dan antijamur telah dilaporkan baik ekstrak maupun senyawa dari M. calabura. Sibi et al. (2012) melaporkan uji aktivitas antibakteri pada ekstrak aquades dan metanol $M$. calabura yang berasal dari daun (EAQDMC/EMDMC), batang (EAQBTMC/EMBTMC) dan buah (EAQBMC/EMBMC). Uji aktivitas dilakukan dengan metode agar well diffusion dengan DMSO sebagai kontrol negatif terhadap beberapa bakteri yaitu Bacillus cereus, Klebsiella pneumonia, Micrococcus luteus, Proteus vulgaris, Pseudomonas aeruginosa dan Serratia marcescens. Aktivitas diukur berdasarkan nilai diameter area penghambatan dengan skala antibiotik HiMedia setelah 24 jam inkubasi. Hasil uji aktivitas antibakteri menunjukkan bahwa ekstrak aquades dan metanol menunjukkan aktivitas penghambatan paling baik terhadap M. luteus. Sedangkan aktivitas antijamur ditunjukkan oleh ekstrak metanol daun dan batang terhadap Fusarium sp dengan area penghambatan masing-masing 30 dan $20 \mathrm{dm}$ dan area penghambatan Penicillium $s p$ masing-masing 26 dan $20 \mathrm{dm}$ (Sibi et al., 2012). Ekstrak metanol akar M. calabura (EMAMC) juga menunjukkan aktivitas antijamur terhadap Alternaria solani $(2,3 \pm 0,17 \mathrm{~cm})$, Fusarium oxysporum f.sp. lycopersici $(2,0 \pm 0,46 \mathrm{~cm})$, Phytophthora sp $(1,8 \pm 0,12 \mathrm{~cm})$, Rhizoctonia solani $(1,5 \pm 0,17 \mathrm{~cm})$, Aspergillus niger $(1,6 \pm 0,09 \mathrm{~cm})$ dan Colletotrichum $\mathrm{sp}(1,7 \pm 0,06$ $\mathrm{cm})$. Berdasarkan hasil penelitian tersebut, ekstrak metanol M. calabura berpotensi sebagai antijamur (Rajesh et al., 2014). Pada penelitian selanjutnya, Sibi et al. (2013) melaporkan minimum inhibitory concentration (MIC) dari beberapa ekstrak buah M. calabura terhadap jenis bakteri yang berbeda dari penelitian sebelumnya. Ekstrak yang digunakan meliputi ekstrak petroleum eter (EPEBMC), kloroform (EKBMC), etil asetat (EEABMC), aseton 
(EABMC), metanol (EMBMC) dan aquades (EAQBMC). Uji MIC dilakukan dengan metode well diffusion dan broth dilution terhadap bakteri yaitu Bacillus cereus, Bacillus subtilis, Staphylococcus aureus, Escherichia coli, Salmonella typhi, Shigella flexneri dan Candida albicans. Hasil uji menunjukkan bahwa EPEBMC dan EKBMC tidak aktif menghambat sebagian besar patogen yang diujikan. Sedangkan EABMC menunjukkan aktivitas penghambatan paling signifikan terhadap B. cereus, B. subtilis, S. aureus dan S. flexneri dengan nilai MIC $10-40 \mu \mathrm{g} / \mathrm{mL}$.

Aktivitas antibakteri dari ekstrak etanol daun (EEDMC) dan batang (EEBTMC) $M$. calabura telah dilaporkan oleh Buhian et al. (2016). Uji aktivitas antibakteri dilakukan dengan metode disc diffusion pada bakteri P. aeruginosa, S. typhimurium, S. aureus dan B. subtilis. EEDMC dan EEBTMC memberikan aktivitas penghambatan dan nilai MIC yang baik terhadap $P$. aeruginosa dan $S$. aureus dengan area penghambatan masing-masing 20,0 mm (MIC 2,5 $\mathrm{mg} / \mathrm{mL}$ ) dan 37,7 mm (MIC 1,25 mg/mL) untuk EEDMC dan 15,7 mm (MIC 2,5 mg/mL) dan 24,7 mm (MIC 1,25 mg/mL) untuk EEBTMC (Buhian et al., 2016). Selain pada ekstrak, uji aktivitas antibakteri juga dilakukan pada senyawa (4), (18), (19) dan (20) yang diisolasi dari ekstrak metanol daun M. calabura. Uji aktivitas dilakukan dengan metode micro-dilution broth dengan nilai MIC paling baik ditunjukkan oleh senyawa (4) $(50 \mu \mathrm{g} / \mathrm{mL}$ terhadap methicillinsensitive Staphylococcus aureus (MSSA) dan $100 \mu \mathrm{g} / \mathrm{mL}$ terhadap methicillin-resistant Staphylococcus aureus (MRSA)) (Sufian et al., 2013). Berdasarkan studi literatur, ekstrak dari M. calabura aktif melawan bakteri gram positif (B. cereus, B. subtilis, S. aureus, S. flexneri) maupun negatif (P. aeruginosa) sehingga M. calabura sangat berpotensi sebagai antibakteri.

\section{Antikanker}

Sejak abad 19, sebagian besar senyawa isolasi dari M. calabura dilaporkan sebagai antikanker. Senyawa tersebut merupakan golongan dari flavonoid. Kaneda et al. (1991) melaporkan uji aktivitas antikanker pada beberapa sel yaitu BC1 (human breast cancer), HT1080 (human fibrosarcoma), Lu1 (human lung cancer), Me12 (human melanoma), Co12 (human colon cancer), KB (human nasopharyngeal carcinoma), KB-V (vincristine-resistant KB) dan P-388 (murine lymphocytic leukemia). Hasil uji sitotoksisitas menunjukkan bahwa 3 senyawa flavan (90), (96) dan (98) aktif terhadap sel-sel tersebut dengan nilai penghambatan secara berurutan 20,0; 4,0 dan 0,8 $\mu \mathrm{g} / \mathrm{mL}$ (Kaneda et al., 1991). Selain itu, uji sitotoksisitas pada sel-sel yang sama juga dilakukan terhadap senyawa (4) (Sufian et al., 2013; Chen et al., 2005; Nshimo et al., 1993). Senyawa (4) memiliki sitotoksisitas yang baik terhadap sel kanker leukimia (P-388) dan kanker kolon (HT-29) dengan nilai $\mathrm{IC}_{50}$ masing-masing 0,21 dan 1,20 
$\mu \mathrm{g} / \mathrm{mL}$ dengan kontrol positif mithramycin (Chen et al., 2005). Selain itu, senyawa (4) juga memiliki efek sitotoksik terhadap sel kanker leukimia (HL60), kanker payudara (MCF7) dan kanker hati (WRL68) dengan nilai IC $_{50}$ masing-masing 3,43; 11,78; dan 34,35 $\mu \mathrm{g} / \mathrm{mL}$ dengan kontrol positif doksorubisin (Sufian et al., 2013). Adapun senyawa flavonoid lain yang juga dilaporkan memiliki efek sitotoksik yang baik terhadap sel P.388 adalah senyawa (67) dengan nilai $\mathrm{IC}_{50} 11,1 \pm 1,0 \mu \mathrm{g} / \mathrm{mL}$ (Chen et al., 2004). Selain pada beberapa senyawa, uji sitotoksisitas juga dilakukan pada ekstrak daun M. calabura yaitu ekstrak metanol, petroleum eter, etil asetat dan air. Ekstrak metanol menunjukkan efek sitotoksik paling baik diantara ekstrak yang lain terhadap sel HL60, MCF7, HCT116 dan WRL68 dengan masing-masing nilai IC $_{50}$ 30,90; 34,73; 61,29 dan $>100 \mu \mathrm{g} / \mathrm{mL}$ (Sufian et al., 2013). Berdasarkan studi literatur, senyawa (4) merupakan senyawa yang sangat berpotensi sebagai antikanker.

\section{Anti-inflamasi}

Anti-inflamasi berfungsi sebagai obat dalam penyembuhan penyakit radang (Yuliana and Fatmawati, 2018). M. calabura dilaporkan memiliki aktivitas anti-inflamasi oleh Zakaria et al. (2007a). Uji aktivitas dilakukan dengan metode carrageenan-induced paw edema pada ekstrak aquades daun (EAQDMC). Hasil uji menunjukkan EAQDMC (27 dan 135 mg/Kg) memberikan aktivitas signifikan lebih besar dibandingkan asam asetilsalisilat (ASA) (100 $\mathrm{mg} / \mathrm{Kg}$ ) (Zakaria et al., 2007a). Dengan metode yang sama, aktivitas anti-inflamasi pada ekstrak polifenol dan metanol $M$. calabura juga telah dilaporkan. Uji aktivitas dilaporkan secara in vivo dengan dua metode yaitu carrageenan-induced paw edema dan cotton pelletinduced granuloma. Hasil uji menunjukkan bahwa ekstrak polifenol (400 mg/Kg) mampu menghambat inflamasi edema hingga 68,87\% yang dibandingkan dengan standar indometasin $(81,92 \%)$. Sedangkan granuloma mampu dihambat oleh ekstrak polifenol (400 mg/Kg) hingga $55,64 \%$ dan dibandingkan dengan obat pembanding naprosen $(64,28 \%)$. Hal ini menunjukkan bahwa ekstrak polifenol mampu menangkal radikal bebas dan menurunkan kadar peroksidasi lipid (LPO) (Gomathi et al., 2013). Kemudian ekstrak metanol buah (300 mg/Kg) dilaporkan mampu menghambat edema hingga $62,43 \%$ dibandingkan dengan standard indomethacin (80,48\%) (Preethi et al., 2012). Selain itu, ekstrak metanol daun (EMDMC) juga dilaporkan memiliki aktivitas anti-inflamasi. Uji aktivitas dilakukan dengan dua metode in vitro yaitu uji lipoksigenase dan santinoksidase. EMDMC (100 mg/mL) memberikan efek penghambatan signifikan terhadap lipoksigenase sebesar $87,65 \%$ dan santinoksidase dengan nilai penghambatan 51,89\% (Zakaria et al., 2014a). Selanjutnya, Balan et al. (2015) melaporkan aktivitas anti-inflamasi dengan metode yang sama dengan Zakaria et al. (2014a) terhadap 
fraksi petroleum eter, etil asetat dan aquades yang diperoleh dari ekstrak metanol. Hasil uji menunjukkan bahwa fraksi etil asetat memberikan prosentase penghambatan paling tinggi dibandingkan dengan fraksi lain dengan nilai penghambatan 95,54\% terhadap lipoksigenase dan 72,81\% terhadap santinoksidase (Balan et al., 2015).

\section{KESIMPULAN}

M. calabura merupakan salah satu bahan alam yang digunakan sebagai obat tradisional atau jamu oleh masyarakat. Konstituen kimia dari tanaman ini telah dibuktikan secara ilmiah mengandung senyawa golongan flavonoid dan memiliki aktivitas biologis yang baik. Oleh karena itu, tanaman M. calabura sangat berpotensi di bidang farmakologi sebagai tanaman obat. Selain itu, penelitian lebih lanjut juga perlu dilakukan untuk uji bioaktivitas senyawa dari M. calabura yang belum banyak diungkap.

\section{DAFTAR PUSTAKA}

Balan, T., Sani, M. H. M., Ahmad, S. H. M., Suppaiah, V., Mohtarrudin, N., Jamaludin, F., and Zakaria, Z. A. 2015. Antioxidant and anti-inflammatory activities contribute to the prophylactic effect of semi-purified fractions obtained from the crude methanol extract of Muntingia calabura leaves against gastric ulceration in rats. Journal of Ethnopharmacology 164, 1-15.

Buhian, W. P. C., Rubio, R. O., Valle, D. L. J., and Puzon, J. J. M. 2016. Bioactive metabolite profiles and antimicrobial activity of ethanolic extracts from Muntingia calabura L. leaves and stems. Asian Pacific Journal of Tropical Biomedicine 6(8), 682-685.

Buhian, W. P. C., Rubio, R. O., and Puzon, J. J. M. 2017. Chromatographic fingerprinting and free-radical scavenging activity of ethanol extracts of Muntingia calabura L. leaves and stems. Asian Pacific Journal of Tropical Biomedicine 7(2), 139-143.

Chen, J. J., Lin, R. W., Duh, C. Y., Huang, H. Y., and Chen, I. S. 2004. Flavones and Cytotoxic Constituents from the Stem Bark of Muntingia calabura. Journal of the Chinese Chemical Society 51, 665-670.

Chen, J. J., Lee, H. H., Duh, C. Y., and Chen, I. S. 2005. Cytotoxic Chalcones and Flavonoids from the Leaves of Muntingia calabura. Planta Med 71, 970-973.

Chen, J. J., Lee, H. H., Shih, C. D., Liao, C. H., Chen, I. S., and Chou, T. H. 2007. New Dihydrochalcones and Anti-Platelet Aggregation Constituents from the Leaves of Muntingia calabura. Planta Med 73, 572-577.

Fatmawati, S., Shimizu, K., and Kondo, R. 2011a. Ganoderol B: A potent alphaglucosidase inhibitor isolated from the fruiting body of Ganoderma lucidum. Phytomedicine 18, 1053-1055. 
Fatmawati, S., Shimizu, K., and Kondo, R. 2011b. Structure-activity relationships of ganoderma acids from Ganoderma lucidum as aldose reductase. Bioorganic \& Medicinal Chemistry Letters 21, 7295-7297.

Fitriana, W. D., Ersam, T., Shimizu, K., and Fatmawati, S. 2016. Antioxidant Activity of Moringa oleifera Extracts. Indonesian Journal Chemistry 16(3), 297-301.

Gomathi, R., Anusuya, N., and Manian, S. 2013. A Dietary Antioxidant Supplementation of Jamaican Cherries (Muntingia calabura L.) Attenuates Inflammatory Related Disorders. Food Science Biotechnology 22(3), 787-794.

Hidayati, M. D., Ersam, T., Shimizu, K., and Fatmawati, S. 2017. Antioxidant Activity of Syzygium polyanthum Extracts. Indonesian Journal Chemistry 17(1), 49-53.

Ibrahim, I. A. A., Abdulla, M. A., Abdelwahab, S. I., Bayaty, F. A., and Majid, N. A. 2012. Leaves Extract of Muntingia calabura Protects Against Gastric Ulcer Induced by Ethanol in Sprague-Dawley Rats. Clinical and Experimental Pharmacology 5, 1-6.

Kaneda, N., Pezzuto, J. M., Soejarto, D. D., Kinghorn, A. D., and Farnsworth, N. R. 1991. Plant Anticancer Agents, XLVIII. New Cytotoxic Flavonoids from Muntingia calabura Roots. Journal of Natural Products 54(1), 196-206.

Khan, M. A. Y., Ramadas, D., Mundasada, S. C., Kumar, S. N., Kashyap, H. R., and Chikkanna, D. 2015. In Vitro Anti-Diabetic Activity of Muntingia calabura root proteins. Biotechnology and Sciences 4(10), 1526-1534.

Kuo, W. L., Liao, H. R., and Chen, J. J. 2014. Biflavans, Flavonoids, and a Dihydrochalcone from the Stem Wood of Muntingia calabura and Their Inhibitory Activities on Neutrophil Pro-Inflammatory Responses. Molecules 19, 521-535.

Mahmood, N. D., Nasir, N. L. M., Rofiee, M. S., Tohid, S. F. M., Ching, S. M., Teh, L. K., Salleh, M. Z., and Zakaria, Z. A. 2014. Muntingia calabura: A review of its traditional uses, chemical properties, and pharmacological observations. Pharmaceutical Biology 52(12), 1598-1623.

Nshimo, C. M., Pezzuto, J. M., Kinghorn, A. D., and Farnsworth, N. R. 1993. Cytotoxic Constituents of Muntingia calabura Leaves and Stems Collected in Thailand. International Journal of Pharmacology 31(1), 77-81.

Preethi, K., Vijayalakshmi, N., Shamna, R., and Sasikumar, J. M. 2010. In Vitro Antioxidant Activity of Extracts from Fruits of Muntingia calabura Linn. from India. Pharmacognosy Journal 2(14), 11-18.

Preethi, K., Premasudha, P., and Keerthana, K. 2012. Anti-inflammatory Activity of Muntingia calabura Fruits. Pharmacognosy Journal 4(30), 51-56.

Putri, D. A., Ulfi, A., Purnomo, A. S., and Fatmawati, S. 2018. Antioxidant and antimicrobial activities of Ananas comosus peel extracts. Mlaysian Journal of Fundamental and Applied Sciences 14(2), 307-311.

Rajesh, R., Jaivel, N., and Marimuthu, P. 2014. Antifungal metabolite from Muntingia calabura root against early leaf blight of tomato. Journal of Medicinal Plant Research 8(17), 646-656.

Rofiee, M. S., Yusof, M. I. M., Hisam, E. E. A., Bannur, Z., Zakaria, Z. A., Somchit, M. N., Teh, L. K., and Salleh, M. Z. 2015. Isolating the metabolic pathways involved in the hepatoprotective effect of Muntingia calabura against $\mathrm{CCl}_{4}$-induced liver injury using LCMS Q-TOF. Journal of Ethnopharmacology 166, 109-118. 
Sani, M. H. M., Zakaria, Z. A., Balan, T., Teh, L. K., and Salleh, M. Z. 2012. Antinociceptive Activity of Methanol Extract of Muntingia calabura Leaves and the Mechanisms of Action Involved. Hindawi 2012, 1-10.

Sibi, G., Naveen, R., Dhananjaya, K., Ravikumar, K. R., and Mallesha, H. 2012. Potential use of Muntingia calabura L. extracts against human and plant pathogens. Pharmacognosy Journal 4(34), 44-47.

Sibi, G., Kaushik, K., Dhananjaya, K., and Ravikumar, K. R. 2013. In vitro antimicrobial activity of Muntingia calabura fruit extracts against food borne pathogens. Pharmacognosy Journal 5(3), 135-136.

Siddiqua, A., Premakumari, K. B., Sultana, R., Vithya, V., and Savitha, S. 2010. Antioxidant activity and Estimation of Total Phenolic Content of Muntingia calabura by Colorimetry. International Journal of ChemTech Research 2(1), 205208.

Sindhe, A. M., Bodke, Y. D., and Chandrashekar, A. 2013. Antioxidant and in vivo antihyperglycemic activity of Muntingia calabura leaves extracts. Der Pharmacia Lettre 5(3), 427-435.

Sridhar, M., Thirupathi, K., Chaitanya, G., Kumar, B. R., and Mohan, G. K. 2011. Antidiabetic effect of leaves of Muntingia calabura L., In normal and alloxaninduced diabetic rats. Pharmacologyonline 2, 626-632.

Su, B. M., Park, E. J., Vigo, J. S., Graham, J. G., Cabieses, F., Fong, H. H. S., Pezzuto, J. M., and Kinghorn, A. D. 2003. Activity-guided isolation of the chemical constituents of Muntingia calabura using a quinone reductase induction assay. Phytochemistry 63, 335-341.

Sufian, A. S., Ramasamy, K., Ahmat, N., Zakaria, Z. A., Izwan, M., and Yusof, M. 2013. Isolation and identification of antibacterial and cytotoxic compounds from the leaves of Muntingia calabura L.. Journal of Ethnopharmacology 146, 198-204.

Vijayanand, S. and Thomas, A. S. 2016. Screening of Michelia champacca and Muntingia calabura extracts for potential Bioactives. International Journal of Pharma Sciences and Research 7(6), 266-273.

Yuliana and Fatmawati, S. 2018. Senyawa Metabolit Sekunder dan Aspek Farmakologi Alocasia macrorrhizos. Akta Kimia Indonesia 3(1), 141-158.

Yusof, M. I. M., Salleh, M. Z., Kek, T. L., Ahmat, N., Azmin, N. F. N., and Zakaria, Z. A. 2013. Activity-guided isolation of bioactive constituents with antinociceptive activity from Muntingia calabura L. Leaves using the formalin test. Hindawi 2013, $1-27$.

Zakaria, Z. A., Hazalin, N. A. M. N., Zaid, S. N. H. M., Ghani, M. A., Hassan, M. H., Gopalan, H. K., and Sulaiman, M. R. 2007a. Antinoceptive, anti-inflammatory and antipyretic effects of Muntingia calabura aquades extract in animal models. Journal of Natural Medicine 61, 443-448.

Zakaria, Z. A., Mustapha, S., Sulaiman, M. R., Jais, A. M. M., Somchit, M. N., and Abdullah, F. C. 2007b. The Antinociceptive Action of Aquades Extract from Muntingia calabura Leaves: The Role of Opioid Receptors. Medical Principles and Practice 16, 130-136. 
Zakaria, Z. A., Mohamed, A. M., Jamil, N. S. M., Rofiee, M. S., Hussain, M. K., Sulaiman, M. R., Teh, L. K., and Salleh, M. Z. 2011. In vitro Antiproliferative and Antioxidant Activities of the Extracts of Muntingia calabura Leaves. The American Journal of Chinese Medicine 39(1), 183-200.

Zakaria, Z. A., Balan, T., Suppaiah, V., Ahmad, S., and Jamaludin, F. 2014a. Mechanism(s) of action involved in the gastroprotective activity of Muntingia calabura. Journal of Ethnopharmacology 151, 1184-1193.

Zakaria, Z. A., Sani, M.H .M., Cheema, M. S., Kader, A. A., Kek, T. L., and Salleh, M. Z. 2014b. Antinociceptive activity of methanolic extract of Muntingia calabura leaves: further elucidation of the possible mechanisms. BMC Complementary \& Alternative Medicine 14(63), 1-12.

Zakaria, Z. A., Sani, M. H. M., Kadir, A. A., Kek, T. L., and Salleh, M. Z. 2016. Antinociceptive effect of semi-purified petroleum ether partition of Muntingia calabura leaves. Brazillian Journal of Pharmacognosy 26(4), 408-419. 